\title{
CONGRESS AND THE PORT OF NEW YORK AUTHORITY: FEDERAL SUPERVISION OF INTERSTATE COMPACTS
}

INTERSTATE compacts, at one time used primarily to formalize state boundary settlements, have been employed increasingly to deal with problems requiring continuing governmental attention. ${ }^{1}$ Article $I$, section 10 , clause 3 of the Constitution provides that "No state shall, without the Consent of Congress . . . enter into any Agreement or Compact with another State ...." Congressional involvement under this clause has normally been limited to reviewing the proposed compact at the time of approval, and imposing conditions or reservations. Recently, however, the House of Representatives authorized the Committee of the Judiciary to investigate "activities and operations of interstate compacts." 2 The Committee began its investigation by looking into the operations of the Port of New York Authority, the largest and most powerful of the commissions created through interstate compacts. ${ }^{3}$ Port Authority officials

1. See Zimmiermann \& Wendell, The Interstate Compact Since 1925, 3-29 (1951) [hereinafter cited as ZIMMIERManN \& WendeLL]. For a general discussion of the history and development of interstate compacts, see Frankfurter \& Landis, The Compact Clause of the Constitution-A Study in Interstate Adjustments, 34 Y YLE L.J. 685 (1925); see also Leach \& Sugg, The Administration of Interstate Compacts (1959) [hereinafter cited as LEACH \& SUGG].

2. H.R. Res. 530, 86th Cong., 2d Sess. (1960), amending H.R. Res. 27, 86th Cong., 1st Sess. (1959). Congress had previously ordered a report from the U.S. Attorney General concerning activities of the commission which administers the Interstate Compact to Conserve Oil and Gas. S.J. Res. 38, 84th Cong., 1st Sess. (1955).

3. Created in 1921 by New York and New Jersey, the Authority was designed to remedy the chaotic commercial conditions existing in the then-competing ports of New York City and northern New Jersey. See Bard, The Port of New York Authorrty 3-63 (1942); Bird, A Study of the Port of New York Authority (1949). A more abbreviated description of the Authority is Goldstein, The Port of New York Authority, 5 J. Puв. L. 408 (1956). Originally financed only by annual appropriations of $\$ 200,000$, Port Compact, article XV, N.J. Stat. Ann. \& 32:1-16 (1940), N.Y. Unconsol. Laws $\$ 6416$, the Authority became self-supporting soon after its creation and has expanded until its present assets total over one billion dollars, 1959 Annual Report, The Port of New YoRK AUTHORITY 71. Its present operations include the administration of twenty-one terminal and transportation facilities; six interstate bridges and tunnels; four air terminals and a heliport; six marine terminal areas; two union motor truck terminals; a motor truck terminal for rail freight; and a union bus terminal. $I \ddot{d}$. at $\mathrm{v}$.

The Port Authority has been described as "perhaps the most efficiently run public works agency in the world," Fortune, The Exploding Metropolis 82 (1958). The factors which lead to efficient operation of public authorities include their similarity to private business institutions, their freedom from niches filled by political patronage, the flexibility of action due to their recent origins, their financial independence from state legislatures, exemption from certain restrictive constitutional provisions of state constitutions, and the obligation of public service felt by the governing commissions. Some of these same factors are pointed out by those arguing that independent authorities receive inadequate supervision. See text at notes $35-48$ infra. 
complied with the Committee's requests for documents of a public nature, but, acting pursuant to orders from the governors of New York and New Jersey, they refused to submit documents dealing with the internal aspects of the Authority's policy making processes. The officials were cited for contempt of Congress by House resolutions, ${ }^{4}$ and the Executive Director of the Port Authority was charged with contempt through an information filed by the United States Attorney for the District of Columbia. 5 In deciding the latter case, courts are faced for the first time with an assertion by Congress of the right to investigate agencies created by interstate agreements.

The congressional right to investigate extends only as far as its legislative powers. ${ }^{6}$ The first question, therefore, is whether Congress has constitutional power to legislate as to activities of interstate agencies.

Legislative authority might be based on a provision in the resolution consenting to the creation of the Port Authority which reserved to Congress the right "to alter, amend or repeal" the terms of the compact. ${ }^{7}$ While Congress can attach binding conditions to its consent, ${ }^{8}$ the compact clause should not be interpreted to grant Congress legislative power over areas otherwise outside its domain. Congress cannot by legislative act confer upon itself the constitutional power to legislate. ${ }^{9}$ Alteration or amendment, therefore, would have to be carried out pursuant to express and implied powers. Similarly, the right to

4. H.R. Res. 606, 86th Cong., 2d Sess., 106 Cong. Rec. 16059 (daily ed. Aug. 23, 1960) (citing A. J. Tobin, Executive Director of the Port Authority) ; H.R. REp. No. 2117, 86th Cong., 2d Sess. (1960) ; H.R. Res. 607, 86th Cong., 2d Sess., 106 Cong. Rec. 16094 (daily ed. Aug. 23, 1960) (citing J. G. Carty, Secretary of the Board of Commissioners of the Port Authority) ; H.R. REP. No. 2121, 86th Cong., 2d Sess. (1960) ; H.R. REs. 608, 86th Cong., 2d Sess., 106 Cong. REc. 16098 (daily ed. Aug. 23, 1960) (citing S. S. Colt, Commissioner of the Port Authority); H.R. REp. No. 2120, 86th Cong., 2d Sess. (1960).

5. See United States Department of Justice, Press Release, Nov. 25, 1960. The Executive Director was charged under 52 Stat. 942 (1938), 2 U.S.C. $\$ 192$ (1959). Prior to the filing of the information, the chairman of the Committee had argued that the U.S. Attorney must obey the statutory instruction "to bring the matter before the grand jury for its action." The Justice Department took the position that the procedure to be followed rested within the discretion of the prosecutor. See Lewis, 3 on Port Board To Be Prosecuted, N.Y. Times, Nov. 17, 1960, p. 1, col. 2.

6. Barenblatt v. United States, 360 U.S. 109, 111-12 (1959) ; Quinn v. United States, 349 U.S. 155, 161 (1955). Only one case has set aside a contempt conviction because the legislative purpose was unconstitutional. Kilbourn v. Thompson, 103 U.S. 168 (1918) (Congress has no "general power of making inquiry into the private affairs of the citizen"). More recent decisions have undercut even this case by permitting investigations notwithstanding exposure of an individual's private affairs, when a legislative. purpose otherwise appears. Barenblatt v. United States, supra at 134; United States v. Josephson, 165 F.2d 82 (2d Cir. 1947), cert. denied, 333 U.S. 838 (1948); see Note, 70 Harv. L. Rev. 671,672 (1957).

7. 42 Stat. 180 (1921).

8. Petty v. Tennessee-Missouri Comm'n, 359 U.S. 275, 281 (1959); James v. Dravo Contracting Co., 302 U.S. 134, 148 (1937) (dictum).

9. Cf. Myers v. United States, 272 U.S. 52, 161 (1926); Coyle v. Smith, 221 U.S. 559, 574 (1911). See also Note, 73 HARv. L. Rev. 1595, 1609 (1960). 
repeal must also be grounded on constitutional authority. In brief, the reservation clause itself is meaningless. ${ }^{10}$

The first constitutional basis for legislative authority might be the compact clause itself. It can be argued that the compact clause authorizes Congress not only to withhold consent initially, but also to revoke consent once granted.11 Revocation would be a form of legislation, presumably carrying with it a general inquisitorial power. This argument assumes, of course, that the agreement in question is a "compact or agreement" within the meaning of article I, section 10. This assumption may not be valid in all cases. A frequently cited dictum from the Supreme Court's opinion in Virginia v. Tennessee ${ }^{12}$ states that only those compacts tending "to the increase of political power in the states, which may encroach upon or interfere with the just supremacy of the United States" require congressional consent for their validity. State courts have relied on this distinction in upholding unapproved interstate agreements against challenges by private parties. ${ }^{13}$ Members of Congress have also espoused the "political power" doctrine; a compact which established the Southern Region Education Board was referred to committee in 1948 for a determination of whether the compact required congressional approval, and was finally put into operation without approval. ${ }^{14}$ Indeed, many interstate agreements have been put into operation without even seeking the assent of Congress. ${ }^{15}$ While the "political power" test is too vague to apply with any certainty, it is at least possible that the Port Authority Compact, having no demonstrable effect on the power of the contracting states vis-à-vis the federal government, would

10. This has been recognized by Congress. In a conference committee report which restored such a provision to a consent bill, the possibility of its being ineffectual was recognized, but it was decided to retain the provision

if for no other reason than that Congress has been doing so in many instances for some 47 years and omitting it from the legislation could give rise to the inference that Congress is foreclosing itself from amending the act at some later date.

H.R. REP. No. 2234, 85th Cong., 2d Sess. 4 (1957) ; see Louisville Bridge Co. v. United States, 242 U.S. 409,418 (1917) (right to amend legislation need not be expressly reserved).

11. Since Congress has never attempted to revoke its consent to an interstate compact, the legal consequences of such an action are not clear. Certainly a bare resolution withdrawing consent would create enormous confusion in the Porf Authority situation, where the administration of a considerable amount of valuable property is involved. But see. Sanitary District v. United States, 266 U.S. 405, 431 (1925) ("The investment of property in the ... works took the risk that Congress might render it valueless by the exercise of paramount powers.").

12. 148 U.S. 503,519 (1893).

13. See Ham v. Maine-New Hampshire Bridge Authority, 92 N.H. 268,30 A.2d 1 (1943) (interstate bridge agreement) ; Dixie Wholesale Grocery, Inc. v. Martin, $278 \mathrm{Ky}$. 705, 129 S.W.2d 181, cert. denied, 308 U.S. 609 (1939) (administrative agreement). See also State v. Lauridsen, 312 S.W.2d 140 (Mo. Sup. Ct. 1958) (reciprocity statute); Landes v. Landes, 1 N.Y. 2d 358, 153 N.Y.S.2d 14, 135 N.E.2d 562 (1956) (Uniform Support of Dependents Law).

14. See Zimmermann \& Wendell 39-40.

15. Id. at 37 . 
have been a valid enactment without congressional approval. The fact that Congress has actually approved the compact does not compel the contrary conclusion, for submission of a compact to Congress is a voluntary act of the states concerned.

Commentators, recognizing the existence of many unapproved compacts, have not denied that they are valid enactments. They maintain, however, that all agreements between states are voidable-that Congress could invalidate any interstate agreement by affirmative action..$^{16}$ This view of "valid but voidable" seems irreconcilable with the words of the compact clause. Since section 10 seems unequivocal in its prohibition of unapproved agreements, it seems doubtful that an agreement can be valid without congressional consent and yet still be a "compact or agreement" for purposes of congressional prohibition. On the other hand, the "valid but voidable" interpretation may be the only practical way of interpreting section 10 to achieve its purpose of preventing conflict between these agreements and the interests of the federal government and other states. ${ }^{17}$ Since serious conflicts may arise from agreements which do not meet the "political" test, Congress must have plenary power to review all. ${ }^{18}$ Yet to require actual review of every agreement would create an intolerable burden on both Congress and the enacting States.

Even if power under the compact clause were lacking, Congress might still legislate under its enumerated powers. In view of the Port Authority's impact on interstate commerce, there seems little doubt that Congress could legislate in the area. The fact that the House Committee's enabling resolution refers only to "interstate compacts" should not alter this conclusion. The resolution does not name the specific congressional power on which it rests, ${ }^{19}$ and since the common meaning of "interstate compact" certainly includes the Port Authority compact, the committee should be entitled to invoke any congressional power which can support that command.

The fact of prior congressional approval of the Port Authority compact might provide a second line of defense. In 1838, the Supreme Court interpreted congressional consent under the compact clause as an act which restores states to their original inherent sovereignty, so that agreements made in this manner have "the same effect as a treaty between sovereign powers." ${ }^{20}$ In theory, the

16. Id. at 40; Dunbar, Interstate Compacts and Congressional Consent, $36 \mathrm{VA}$. L. Rev. 753, 762 (1950) ; Comment, 45 Y ALE L.J. 324, $327-28$ (1935). But see Note, 35 Colum. L. REv. 76, 84-85 (1935).

17. For discussion of the purpose of the clause, see Frankfurter \& Iandis, "sipra note 1 , at 694-95.

18. Ibid.

19. The general enabling resolution, H. R. REs. 27, 86th Cong., 1st Sess. (1960), provides: "That the Committee on the Judiciary . . . is authorized and directed to conduct ... investigations and studies relating to the following matters coming within the jurisdiction of the committee, namely-[immigration laws, claims against the United States, penal institutions, federal courts, antitrust laws, criminal statutes, and the submerged Lands Act and Outer Continental Shelf Lands Act]."

20. Rhode Island v. Massachusetts, 37 U.S. (12 Pet.) 657, 724 (1838). 
compact stands as the act of an equal sovereign, unimpeachable by Congress. Irrevocable consent is not unknown in the Constitution, for an analogy is found in the admission of states into the Union. ${ }^{21}$ Presumably no one would maintain that Congress could end the existence of thirty seven states by revoking its consent to their admission. On the other hand, this ancient view would block exercise of Congress' plenary powers in areas covered by interstate compacts. And by failing to allow for changed circumstances, which might alter the impact of the agreement, irrevocability of consent would also frustrate the protective purposes of the compact clause. The one commentator to suggest that withdrawal of consent alone could not disturb the "treaty" has recognized exceptions to this doctrine to provide for both these dangers: the compact can be terminated if it conflicts with an exercise of plenary congressional power, or if circumstances have changed. ${ }^{22}$ The Port Authority charter would probably be revocable on both grounds, the second because the Authority has acquired extensive additional powers since its inception in $1921 . .^{23} \mathrm{~A}$ better approach would be to disregard the idea of irrevocability altogether. Since it must be qualified practically out of existence by the "changed circumstances" exception, the concept serves only to introduce another false issue into the interpretation of the compact clause.

The Authority challenges the congressional investigative power on still another ground, arguing that documents pertaining to internal operations of an agency performing state functions, created and regulated by the states, are beyond the reach of congressional subpoena. ${ }^{24}$ Both state and federal courts have regarded the Port Authority as a state agency for a variety of purposes, such as exemption from municipal taxation of its realty, ${ }^{25}$ from federal taxation of the interest on its bonds ${ }^{26}$ from the operation of local ordinances, ${ }^{27}$ and from restrictions placed on private persons by state laws. ${ }^{28}$ In addition, the

21. U.S. Const. art. IV, § 3. See Coyle v. Smith, 221 U.S. 559, 567 (1911) ; Mora v. Torres, 113 F. Supp. 309 (D.P.R. 1953) (Congress cannot unilaterally amend agreement with Puerto Rico "in the nature of a compact").

22. Note, 35 Colun. L. Rev. 76, 84-85 (1935).

23. See note 3 supra.

24. See Brief in Support of Motion for Judgment of Acquittal, pp. 23-60, United States v. Tobin, Cr. No. $986-60$ (D.D.C. 1960).

25. Port of New York Authority v. Union City, 19 N.J. Misc. 421, 20 A.2d 653 (Sup. Ct. 1941) ; Bush Terminal Co. v. New York, 282 N.Y. 306, 26 N.E.2d 269 (1940) (by implication).

26. Commissioner v. Shamberg's Estate, 144 F.2d 998, 1004 (2d Cir.), cort. dertied, 323 U.S. 792 (1944). See also Helvering v. Gerhardt, 304 U.S. 405 (1938).

27. Port of New York Authority v. Weehawken, 27 N.J. Super. 328, 99 A.2d 317 (Super. Ct. 1953).

28. Port of New York Authority v. J. E. Linde Paper Co., 205 Misc. 110, 127 N.Y.S.2d 155 (N.Y. Munic. Ct. 1953) ("The Port Authority . . . is immune from the unilateral imposition of a burden or restriction on its powers by taxation or regulation of one of the States."). 
Port Authority has been held entitled to sovereign immunity. ${ }^{29}$ The federal government itself has provided grant-in-aid funds to the Port Authority under provisions allocating such monies to "states." 30

But even if the Authority is an agency of the states, such a status would not immunize its files from congressional investigation. In addition to the preemptive effect of federal legislation upon conflicting state enactments, the powers of Congress probably extend to regulation, and therefore investigation, of state agencies themselves. ${ }^{31}$ The Supreme Court has held a state-operated railway subject to criminal penalties when the trains were operated in violation of a federal statute, even though the railway was "acting within a power reserved to the states." 32 The theory that state documents are sacrosanct when dealing with wholly internal matters was recently rejected. In re Wallace ${ }^{33}$ involved an attempt by the Civil Rights Commission to inspect voting records of the state of Alabama. State election officials had not responded to a court order, and a motion was filed in the District Court for an order to enforce compliance. The state officials claimed, inter alia, that examination by federal officials constituted an illegal invasion of state sovereignty. Insisting that its order be obeyed, the court held that

the sovereignty of the State of Alabama, or any other of the states, must yield ... to this expression of Congress ... passed in a proper exercise of a power specifically delegated to the Federal Government. ${ }^{34}$

Congressional investigation of interstate agencies such as the Port Authority may be desirable in view of their relative freedom from both state and federal regulation. ${ }^{35}$ States take the initiative in creating these agencies, and assume responsibility for their direction and control. Opportunity for regulation is afforded by usual controls such as the appropriations power, the appointment

29. Voorhis v. Cornell Contracting Corp., 170 Misc. 908, 912, 10 N.Y.S.2d 378, 381 (N.Y. City Ct. 1938) ; Howell v. Port of New York Authority, 34 F. Supp. 797 (D.N.J. 1940). But cf. Petty v. Tennessee-Missouri Bridge Comm'n, 359 U.S. 275, 283 (1959) (concurring opinion) (dictum) (applicability of Eleventh Amendment to bistate agencies an open question).

30. E.g., Federal Airport Act, 60 Stat. 170 (1946), 49 U.S.C. $\S \S 1101-19$ (1958); see 1952 Annual Report, The Port of New York Authority 85. On occasion, a distinction is made between state and bistate agencies. E.g., 69 Stat. 643 (1955), 42 U.S.C. $\S 1492$ (a) (1958) ; 70 Stat. 1044 (1956), 43 U.S.C. $\$ 422(\mathrm{~b}),-$ (c) (1958). The Port Authority's dealings with the federal government are in the nature of arms length transactions. See Goldstein, The Port of New York Authority, 5 J. PuB. L. 408, $411-12$ (1956); 1959 ANNUAL Report, PORT OF NEW YoRk AuthorITy 45.

31. Investigation is not regulation, ICC v. Goodrich Transit Co., 224 U.S. 194, 211 (1912), but the power to regulate implies a power to investigate, Oklahoma Press Publishing Co. v. Walling, 327 U.S. 186, 210 (1946).

32. United States v. California, 297 U.S. 175, 183-84 (1935); see Stern, The Commerce Clanse asd the National Economy, 1933-1946, 59 HARv. L. Rev. 645, 663 (1946).

33. 170 F. Supp. 63 (M.D. Ala. 1959).

34. Id. at 67.

35. For discussion of state restraints with respect to the Port Authority, see BARD, The Port of New York Authority 269-72 (1942). 
power, and gubernatorial veto. ${ }^{96}$ But because of the compact agency's unfamiliar character and lack of integration into the state administrative structure, little control is imposed in practice. ${ }^{37}$ Moreover, modification of existing policy may be hindered by the need for joint action of two or more state legislatures. ${ }^{3 s}$ Nor can judicial control be relied upon to protect the national interest. Whereas both state and federal courts take responsibility for weighing the burden of state legislation on interstate commerce, ${ }^{39}$ they appear to be reluctant to engage in an analogous examination of the national interest when an interstate compact is involved. Holding that 1951 legislation modifying a 1921 interstate compact was necessarily "congressionally approved," one court has refused even to examine the legislation to see if it fell within the scope of the consent given by Congress. ${ }^{40}$

Existing congressional controls over interstate agencies are of little or no regulatory importance. Congress does not usually have the power to block appointments ${ }^{41}$ or control appropriations, devices which give it at least some control over federal agencies. Congressional restraints include various reservation clauses ${ }^{42}$ consent of limited duration, ${ }^{43}$ restrictions on further state legislation without congressional approval, ${ }^{44}$ requirements of periodic reports to Congress, ${ }^{45}$ and the right to examine books and records. ${ }^{46}$ These are inefficient tools for initiating affirmative national policy guides. ${ }^{47}$ Moreover, since inter-

36. LEACH \& SUGG at $25-49$.

37. Ibid.

38. Thursby, InTerstate Cooperation 13-14 (1953); Clark, Interstate Compacts and Social Legislation, 51 Pox. Scr. Q. 36 (1936).

39. E.g., Southern Pac. R.R. v. Arizona, 325 U.S. 761 (1945) ; Williams v. Stockham Valves \& Fittings Inc., 213 Ga. 713, 101 S.E.2d 197 (1957), rev'd, 358 U.S. 450 (1959).

40. Wolkstein v. Port of New York Authority, 178 F. Supp. 209, 213 (D.N.J. 1959). No court has ever invalidated an interstate agreement on any grounds. One factor which may cause greater judicial deference when dealing with interstate compacts is the state courts' awareness that their decisions will affect relations with other states. See, e.g., Commonwealth ex rel. Smith v. Clark, $331 \mathrm{~Pa} .405,415,200$ Atl. 41, 46 (1938).

41. In at least one case, however, Congress has provided that the President appoint commissioners to represent the interests of the United States. Ohio River Valley Water Sanitation Compact, article XI, \& 3, 54 Stat. 756 (1940).

42. E.g., 65 Stat. 671 (1951).

43. Interstate Compact to Conserve Oil and Gas, 49 Stat. 941 (1935) ; Atlantic States Marine Fisheries Compact, 56 Stat. 267 (1942).

44. Bi-State Development Agency Compact, 64 Stat. 571 (1950).

45. Atlantic States Marine Fisheries Compact, 56 Stat. 270 (1942); Pacific Marine Fisheries Compact, 61 Stat. 422 (1947).

46. New York-New Jersey Transportation Agency Compact, 73 Stat. 582 (1959); Wabash Valley Compact, 73 Stat. 699 (1959). All of these conditions are, of course, subject to a determination of their constitutionality.

47. A lack of specific policy direction is especially clear when Congress consents to compacts before they are written. See ZimMararann \& Wendell 91-92. Most consent-inadvance statutes are simply congressional encouragement of interstate cooperation. $I d$. at 92. 
state compact agencies are primarily identified with the state governments, congressional attention to these agencies is likely to be sporadic at best. ${ }^{48}$

Investigation may be required, therefore, both to evaluate the need for supplementary legislation and to impose more subtle controls on agency officials. But a countervailing argument suggests that Congress should use its investigating powers sparingly. Interstate agreements often deal with multistate problems which might otherwise be considered the responsibility of the federal government. State officials who negotiate interstate agreements are frequently aware of this fact, and may be induced to act, in part, by a desire to preserve traditional state authority over the problem area. ${ }^{49}$ The prospect of increased federal interference could thus have a strong inhibitory effect on interstate cooperation. If it does, the national interest may be harmed on balance, for any reduction in state action will ultimately lead to demands for increases in federal activity and expenditures. ${ }^{50}$

In addition to denying congressional investigative power, defendant in the Port Authority case also argues that he was prevented from complying with the subpoena by the orders of his superiors. ${ }^{51}$ The governors of both New York and New Jersey directed the commissioners under their respective jurisdictions to order the three officials involved not to produce certain of the subpoenaed documents. ${ }^{52}$ In some contempt of court cases, this defense has been allowed. When subordinate officials in executive and independent agencies of the federal government have refused to respond to subpoenas of litigants seeking information for use in private lawsuits, ${ }^{53}$ the regulations forbidding disclosure of governmental materials without specific release from higher authority have been held to protect such subordinates from being cited for contempt of court. ${ }^{54}$ Allowance of the subordinates' defense in these cases is not based on a finding that the government has a right to withhold the information. That issue would be tested if the superior himself were subpoenaed. Rather, it rests on a policy

48. See Leach \& Sugg 56.

49. For an example of this attitude, see $i d$. at 196 (Interstate Compact to Conserve Oil and Gas).

50. The increasing need for joint action has often been pointed out. Coxrmission on IntergovernMantal Relations Report 45-47 (New Jersey 1955); Hart, The Relations between State and Federal Law, 54 Colum. L. Rev. 489, 542 (1954). See also Fordham, Decision-Making in Expanding American Urban Life, 21 Oнго Sr. L.J. 274, 281 (1960).

51. See Brief in Support of Motion for Judgment of Acquittal, pp. 98-110, United States v. Tobin, Cr. No. $986-60$ (D.D.C. 1960).

52. The letters ordering the commissioners to refrain from producing the documents are reprinted in H.R. REp. No. 2120, 86th Cong., 2d Sess. 39-41 (1960).

53. When the government is a party, recognition of the binding effect of departmental regulations prohibiting production of documents will not prejudice the opposing litigant, for the government may be compelled to sacrifice its lawsuit as a price for secrecy. Andolshek v. United States, 142 F.2d 503, 506 (2d Cir. 1944).

54. United States ex rel. Touhy v. Ragen, 340 U.S. 462 (1950); Appeal of SEC, 226 F.2d 501 (6th Cir. 1955). Whether the highest officials of the executive branch of the federal government have constitutional power to withhold information from Congress or the courts has never been decided. Bishop, The Executive's Right of Privacy: An Un resolved Constitutional Question, 66 Y ALE L.J. 477 (1957). 
of preserving an orderly scheme of access to governmental documents. The defense has been justified on the grounds that the protection of private parties demands that no information be released except as directed by the official ultimately responsible for the effect of the governmental action $;^{55}$ that great confusion would result if freedom to search through files were given $;{ }^{50}$ and simply that the prohibitory regulation has the force of law. ${ }^{67}$ Although seldom mentioned, another reason for allowing the "superior order" defense may be a subordinate's plight when subject to conflicting orders. ${ }^{58}$ Because of these considerations, it is not unreasonable to require the litigant seeking governmental information to proceed against the superior officer himself.

If this defense were allowed in the Port Authority case, Congress could compel production of the information only by acting directly against the Executive Director's superiors, either the Port Authority Commissioners or the governors themselves. ${ }^{59}$ But some of the considerations underlying recognition of the defense in private lawsuits may not be applicable when Congress is the party seeking information. Arguably, the interest of Congress in direct and speedy access to information is greater than that of a private litigant. Moreover, recognizing a congressional right of access would not have the disruptive effect of allowing a multitude of private litigants to roam through Port Authority files. ${ }^{60}$ Of course, the Executive Director is in no less a dilemma than any other official confronted with conflicting orders. But even this difficulty is probably erased by the fact that the subordinate can probably plead the supremacy of the federal order as a defense to any disciplinary action taken by state officials. ${ }^{61}$

55. Boske v. Comingore, 177 U.S. 459, 469-70 (1899).

56. Id. at 470 .

57. Ex parte Sackett, 74 F.2d 922, 924 (9th Cir. 1935).

58. See United States v. Hall, 153 F. Supp. 661, 666 (W.D. Ky. 1957).

59. Congress has, of course, already cited one commissioner for contempt, see note 4 stipra, but no court action has been taken.

60. Documents of a public nature are probably available to anyone. N.Y. Post Corp. v. Moses, 210 N.Y.S.2d 88 (App. Div. 1961).

61. A further weakness of the "superior order" defense in the present case is the possibility that the order not to produce documents was not valid. It is unclear whether the governors' orders are binding on the Authority officials. Although article XVI of the compact reserves to each state the right to provide for the exercise of a veto power by the governor over "actions" of a "commissioner" appointed from his state, PORT AUThorrTy Compact, article XVI, N.J. Stat. Ann. 32:1-17 (1940), N.Y. Unconsol. Laws § 6417, the "action" in article XVI seems to refer to actions taken and voted on at regular meetings of the commissioners. One possible interpretation of the compact, therefore, is that the veto power was meant to apply only to affirmative actions taken by the commissioners themselves, such as approving a proposed project or acquisition of property, 1942 Ops. N.Y. ATT'Y GEN. 390. This interpretation is supported by the fact that article VII of the compact provides for imposition of additional duties on the commissioners only by joint legislative action, Port Authorrty Compacr, article VII, N.J. Stat. Ann. 32:1-8, N.Y. UNCONSOL. LAwS $\$ 6408$. On the other hand, defendant points out that the veto powers of the governors could properly have been invoked if the commissioners had first gone through the formality of voting to furnish the information to Congress. Brief in Support of Motion for Judgment of Acquittal, pp. 107-08, United States v. Tobin, Cr. No. 986-60 (D.D.C. 1960). 